\title{
Do Male and Female Students Learn Differently?
}

\author{
Jamiah \\ jamiah.jamaluddin@yahoo.com \\ Murni Mahmud \\ murnimahmud1973@gmail.com \\ Maemuna Muhayyang \\ maemarasyid@yahoo.co.id \\ State University of Makassar, Indonesia
}

\begin{abstract}
This paper points out the gender differences in English learning.It investigated students' language learning strategies as affected by gender differences. The data collected in 2015 from 15 male students and 15 female students' of second grade at SMA Negeri 11 Makassar. It is to reveal their differences in English learning and the effect of gender differences in choosing language learning strategies. It is indicated that the entire student used six language learning strategies namely memory strategy, cognitive strategy, compensation strategy, metacognitive strateg, affective strategy and social strategy but they had different ways in using them. Mostly, females used social strategy because they were more emphatic, social thinking and like cooperating with their peers while the males refered to the compensation startegy because their characteristics were more confident, fun, logical, active in expressing their opinion. So, it was concluded that gender differences affect in choosing language learning strategies of male and female students at SMA Negeri 11 Makassar.
\end{abstract}

Keywords: language learning strategy, gender differences, classroom interaction

\section{Introduction}

The focus in language education over the past few decades has gradually shifted from the teacher and teaching strategies to the learner and learning strategies. How learners look at and work with the task of learning languages and what types of strategies they utilize to process the new information has become a popular area of the research. That is why, an important issue in education is the understanding and the application of language learning strategy (Oxford, 1990). 
Jamiah, Mahmud, Muhayyang: Do Male and Female Students Learn ... $\mid 111$

The use of language learning strategies had been discusssed by many important acedemicians (Tam, 2013; and Oxford, 1990). Acquainted that language learning strategies had a positive correlation with language achievement and proficiency. With an improved knowledge of appropriate LLSs, learners can actively monitor their learning pattern and greatly improve their language proficiency (Oxford, 1990:45).

In reality, people do not understand everything when they are born, but have to learn everything so that they are able to understand (Lee, 2010:133). Therefore, many researches (Lee, 2010; and Cabaysa, 2010) try to find how learners go about learning something, what makes learners successful at learning something, and why some people are more effective at learning than others.

According to recent research studies (Aslan, 2009; Božinovi, 2011; and Tam, 2013), gender is an important factor affecting the choice of language learning strategies in foreign language learning and is said to have a profound effect on strategy choice of learners (Oxford, 1990).

The situation which brings a foreign language to life in the classroom also appears in SMA Negeri 11 Makassar. This article will also look at difference of male and female of second grade students of SMA Negeri 11 Makassar in learning English and how gender differences affect second grade students in choosing language learning strategies of SMA Negeri 11 Makassar.

\section{Literature Review}

\section{Concept of Learning Strategy}

\section{a. Definition of Learning Strategy}

According to Lee (2010:21), learning strategy is skill of learning, learningto-learn skills, thinking skills, problem skills or, the methods which learners use to intake, store, and retrieve during the learning process. While based on Oxford (1989) language learning strategies are behaviours which learners use to make language learning more successful, self-directed and enjoyable.

b. Characteristics of learning strategies

Oxford (1990) lists basic features of a foreign language learning strategy: 
1) strategies contribute to the main goal-communicative competence

2) strategies allow learners to become more self-directed and to develop autonomous learning and take responsibility for their own learning; they affect the process of learning, the learner's success or failure in learning

3) strategies expand the role of foreign language teachers in a way that the traditional role of the teacher in the educational process changes and the teacher assumes the role of person facilitating the learning, helping, advising, diagnosing, coordinating learning, and participating in communication

4) strategies are problem-oriented

5) strategies are specific actions taken by the learner

c. The Taxonomy of Language Learning Strategies

The taxonomy of language learning strategies proposed by Oxford (1990) comprised six learning strategies and categorized them into direct and indirect strategies.

Table 1. The taxonomy of language learning strategies

\begin{tabular}{|l|l|}
\hline & \multicolumn{1}{|c|}{ Direct Strategies } \\
\hline Memory Stratregy & $\begin{array}{l}\text { E.g. Memorising a word by repeating it } \\
\text { several times } \\
\text { E.g. Deducting the meaning of a word } \\
\text { from its context } \\
\text { E.g. Using a similar word to the one that } \\
\text { is not known by the learner. }\end{array}$ \\
\hline Metacognitive Stratregy & $\begin{array}{l}\text { Planning the learning activity } \\
\text { Affective Strategy }\end{array}$ \\
Secial Strategy & $\begin{array}{l}\text { completion of an activity } \\
\text { Seeking opportunities to converse with } \\
\text { native speakers }\end{array}$ \\
\hline
\end{tabular}

\section{Concept of Gender}

a. Theory of Gender

According to Mahmud (2009:21), gender shaped by social factors and culture that afterwards produced number of opinions about the social and cultural roles of men and women. In this study, the term gender is used following this conceptualization of gender which is composed of culturally constructed male identity and female identity, not the biological differences between males and females. 
Jamiah, Mahmud, Muhayyang: Do Male and Female Students Learn ... $\mid 113$

b. Theory of Gender in English Speaking

Table 2. Female and male students' reasons for expressing opinions

\begin{tabular}{|l|l|}
\hline \multicolumn{1}{|c|}{$\begin{array}{c}\text { Females' reasons to choose } \\
\text { speaking }\end{array}$} & \multicolumn{1}{|c|}{$\begin{array}{c}\text { Males' reasons to choose } \\
\text { speaking }\end{array}$} \\
\hline $\begin{array}{l}\text { Willing to share ideas } \\
\text { More skilled in speaking } \\
\text { Easy, direct, and faster to transfer } \\
\text { ideas }\end{array}$ & $\begin{array}{l}\text { Clear, direct to the point } \\
\text { Effective and fast } \\
\text { Need to be more creative }\end{array}$ \\
\hline
\end{tabular}

(Mahmud, 2010:177)

c. Theory of Gender in Communication

Table 3. Differences on men and women in communication as seen:

\begin{tabular}{|l|l|}
\hline \multicolumn{1}{|c|}{ Male Style } & \multicolumn{1}{c|}{ Female Style } \\
\hline Focus on information & Focus on relationship \\
Report style of speaking & Rapport style of speaking \\
Goal driven & Process oriented \\
Single-task approach & Multi-task approach \\
Succinct language & Storytelling style of speech \\
Working towards a destination & On a journey \\
Need to know the answers & Want to ask the right questions \\
\hline
\end{tabular}

(Tymson,1998:8)

\section{d. Gender in Learning English}

Previous studies have often pointed out that females perform better than males in first language acquisition (Larsen-Freeman \& Long 1991; Dionne et al. 2003 in Tam, 2010:23). Similar patterns have been observed in China, Korea, and the United States, among others. Linguists have tried to explain the observed gender difference in terms of language learning. Oxford (1990) reported that females are more aware of their use of strategies to facilitate 


\section{4| ELT Worldwide Vol. 2 No. 2 October 2015}

their learning. As a result, their overall performance in language acquisition is generally better than that of males.

\section{Concept of Learning English}

a. English as A Foreign Language

Foreign languages are usually taught as one subject in the school with the goal of communicating as well as four basic laguage skills (listening, speaking, reading and writing) in that language within certain limits. Language skills are divided into receptive and productive skill. The receptive skill includes listening and reading because learners do not need to produce language to do these, they receive and understand it. These skills are sometimes known as passive skills while the productive skill is speaking and writing because learners doing these needs to produce language. They are also known as active skills.

\section{Research Method}

This research used a descriptive qualitative. The researcher conducted observation during three meetings by recording students' activities. After doing observation, the researcher interviewed 15 males and 15 females to find out deeply information about howgender differences affected in choosing language learning strategies. The respondents of this research was the 15 males and 15 females second grade students at SMA Negeri 11 Makassaar class XI Science 3.

\section{Findings}

The findings of the research contain the result of data analysisthrough observationand interview to get some empirical evidences about the differences of male and female students' language learning strategies at SMANegeri 11 Makassar and the effect of gender differences in choosing male and female students' language learning strategies at SMANegeri 11 Makassar.

1. The Differences of Male and Female Students' Language Learning Strategies at SMA Negeri 11 Makassar

The result of the observation conducted for three meetings revealed that the male and the female students at SMA Negeri 11 Makasar used six language learning strategies, namely (1) memory strategy, (2) cognitive strategy, (3) 
Jamiah, Mahmud, Muhayyang: Do Male and Female Students Learn ... $\mid 115$

compensation strategy, (4) metacognitive strategy, (5) affective strategy and (6) social strategy. Each strategy is presented in the followong descriptions.

\section{a. Memory Strategy}

Table 4 below presents the male and females students' ways in using memory strategies conducted for three meetings.

Table 4: Students' ways in using memory strategy

\begin{tabular}{|c|c|l|l|}
\hline No. & Meetings & \multicolumn{1}{|c|}{ Male } & \multicolumn{1}{|c|}{ Female } \\
\hline 1. & First & $\begin{array}{l}\text { Using keyword } \\
\text { Using a combination of } \\
\text { sound and image } \\
\text { Using keyword } \\
\text { Second }\end{array}$ & $\begin{array}{l}\text { Using context } \\
\text { Representating sound in } \\
\text { Memory }\end{array}$ \\
Elaborating \\
\hline
\end{tabular}

From all of the male students in three meeting, there were more male students used keyword in entering and retrieving information into memory. Besides that, in second meeting, they also applied a combination of sound and images. They could understand and memorize well by comparing between the speaker and the Indonesian subtitle so they not only learn new words but also learn how to pronunce them. Conversely, female students showed different ways in each meeting. They prefered using context, elaborating and representing sound in memory. They related the new information to existing ones and by listening, they could feel and enjoy the lyrics because they not only learnt new words but also it could touch their heart.

\section{b. Cognitive Strategy}

Table 5 points out the male and female students selected in using cogntive strategy for three meetings

Table 5: Students' ways in using cognitive strategy

\begin{tabular}{|c|c|c|c|}
\hline No. & Meeting & Male & Female \\
\hline 1. & First & Highlighting & Taking notes \\
\hline \multirow[t]{3}{*}{2.} & Second & Getting the ide quickly & -Reasoning inductively \\
\hline & & Traslating & -Translating \\
\hline & & & -Taking note \\
\hline \multirow[t]{2}{*}{3.} & Third & Translating & Transferring \\
\hline & & Highlighting & \\
\hline
\end{tabular}


In understanding and producing the English language, each male and female students had different preferences during three meetings. The ways in applying this strategy, the male students liked highlighting in first and third meeting. They focus on spesific points during instructions. In second meeting, they used skimming to determine the main idea of the text to get the idea quickly and used translating in analysing the text. They did not use their own words. Differently, the female students liked taking notes in two meetings. They liked writing down the important information or material during English learning process. They also tended to begin with specific examples and built the general theory more often than the males. In analyzing the text, the female students prefered translating and transferring. They could retell the text by using their own words.

\section{c. Compensation Strategy}

As indicated in table 6 below shows the compensation strategy used by male and females students conducted for three meetings.

Table 6: Students' ways in using compensation strategy

\begin{tabular}{|c|c|c|c|}
\hline No. & Meeting & Male & Female \\
\hline 1. & First & $\begin{array}{l}\text { Switching to Indonesia } \\
\text { Language } \\
\text { Active }\end{array}$ & $\begin{array}{l}\text {-Using mime and gesture } \\
\text {-Feeling doubt }\end{array}$ \\
\hline 2. & Second & $\begin{array}{l}\text { Active } \\
\text { No doubt }\end{array}$ & $\begin{array}{l}\text { Using synonym, feeling } \\
\text { doubt, Feeling afraid to } \\
\text { make mistake }\end{array}$ \\
\hline 3. & Third & $\begin{array}{l}\text { Direct in giving } \\
\text { explanation } \\
\text { Active }\end{array}$ & More explanation \\
\hline
\end{tabular}

The male and the female students also had different preferences in terms of expressing opinions in English learning. In every meeting, the males were more active and communicative in expressing their opinion than the female at the classroom. They were not doubt in expressing their idea although their answers were direct and switched to Indonesian language while females were more passive at the classroom but clear and complete in expressing their idea. They were doubt and afraid to make mistakes. 


\section{d. Metacognitive Strategy}

During three meetings, the male and female students had differences in applying metacognitive strategy as put in table 7 .

Table 7: Students' ways in using metacognitiive strategy

\begin{tabular}{|c|c|l|l|}
\hline No. & Meeting & \multicolumn{1}{|c|}{ Male } & \multicolumn{1}{c|}{ Female } \\
\hline 1. & First & $\begin{array}{l}\text { Seeking practice } \\
\text { opportunities }\end{array}$ & Paying attention \\
2. & Second & Self-evaluating & Self-monitoring \\
3. & Third & Unwell prepared & Organizing \\
\hline
\end{tabular}

In English learning process, the male and the female students had different preferences. In first until third meeting, the females mostly liked listening, it revealed that they paid attention than the male students. The females liked identifying both their understanding and producing. That is why, they were good in organizing their lerning process. On the contrary, the male students liked evaluating their progress and seeking practice opportunities in front of class but unwell in preparing the lesson.

\section{e. Affective Strategy}

In applying affective strategy, both male and femlae students gave different tendencies that are provided in table 8 .

Table 8: Students' ways in using affective strategy

\begin{tabular}{|c|c|c|c|}
\hline No. & Meeting & Male & Female \\
\hline 1. & First & Making fun & $\begin{array}{l}\text {-Using music } \\
\text {-Discussing their feeling } \\
\text { to others. }\end{array}$ \\
\hline 2. & Second & Making fun & $\begin{array}{l}\text { Discussing their feeling to } \\
\text { others. }\end{array}$ \\
\hline 3. & Third & $\begin{array}{l}\text {-Making fun } \\
\text {-Rewarding themselves }\end{array}$ & Rewarding themselves \\
\hline
\end{tabular}


In English class, the male and the female students had differences in regulating their emotion for lowering their anxiety. Each meeting, the male students liked making fun at the classrom. It was different with the females that preferedusing music and discussed their feeling to others. In the other hand, both the male and the female students also had similarity in rewarding themselves if they were better in answering the questions.

\section{f. Social Strategy}

In using this strategy, as displayed in table 9, the male and female students used social strategy conducted for three meetings.

Table 9: Students' ways in using social strategy

\begin{tabular}{|c|c|l|l|}
\hline No. & Meeting & \multicolumn{1}{|c|}{ Male } & \multicolumn{1}{c|}{ Female } \\
\hline 1. & First & Asking for correction & $\begin{array}{l}\text {-Asking for clarrification } \\
\text {-Cooperating with peers } \\
\text { Cooperating with peers }\end{array}$ \\
3. & Second & $\begin{array}{l}\text { Competitive } \\
\text { Good coordination } \\
\text { Difficult to understand } \\
\text { the emotion }\end{array}$ & $\begin{array}{l}\text { Becoming aware of other } \\
\text { feeling }\end{array}$ \\
\hline
\end{tabular}

Based on the data in table 9, the female students mostly liked asking for clarrification, cooperating with their peers, and becoming aware of other's feeling. Conversely, the male students mostly liked asking for correction, good coordination but difficult to understand the emotion.

Based on the data above, it resulted another important finding was the strategies based-gender differences in learning English by investigating the language learning strategies used by the male and the female students at SMA Negeri 11 Makassar during three meeting that shown in table 10 :

Table 10. Language Strategies based gender differences in learning English

\begin{tabular}{|c|c|c|}
\hline No. & Male students & Female students \\
\hline 1. & Competitive & Collaborative \\
2. & Coordinating & Organizing \\
3. & Deductively & Inductively \\
4. & Highlighting & Personalizing \\
5. & Visual-auditory & Auditory \\
\hline
\end{tabular}


As indicated in Table 10, both the male and the female students at SMA Negeri 11 Makassar had strategies to endure in learning English. For example, the males were motivated by competition while females were not. The males were deductively reasoning. They tend to begin with concrete examples, especially in verbalization and writing, males also liked visualauditory, for males, the most effective way to study language is to learn visually (seeing a written word or illustration) as well as orally (through listening and repetition), moreover, males also were highlighting and coordinating. They liked a simple thing, spesific point, and also good in coordination.

Contradictly, the females preferedcollaborative group in learning. Other strategies were inductively reasoning, the females began with specific examples and built the general theory more often than the males. The female also were organizing, they like making their schedule to manage when they need to learn and have fun. Besides that, they were auditory and personalizing. Even in learning, females preferedlistening, they gave their feelings as the priority. The females also were moody that is why their decision could be influenced by their emotions.

The data above were supported by some scholars (Gurian, 2001; Torrpra, 2008; Aslan, 2009; and Mahmud, 2010). The male and the female students have different strategies in learning English cited by Mahmud (2010). Proofed by the frequecy of social strategy used in table 14 that females used more than males. It was similar with Aslan (2009:65) reported that the females used more social strategy than their counterparts. It is supported also by Torrpra (2008:34) reports that the females could process an abstract piece of language more efficiently whilethe males needed some sensory reinforcement to process the data. In deductive and inductive reasoning, Gurian (2001) states the males tend to do deductive reasoning more quickly than girls. The females, on the other hand, tend to favor inductive thinking.

2. The Effect of Gender Differences in Choosing Male and Female Students' Language Learning Strategies at SMA Negeri 11 Makassar

In learning English, both male and female students at SMA Negeri 11 Makassar had different strategies to achieve their goals in English. The researcher interviewed 15 males and 15 females about their language learning strategies. The interview consists of questions for the male and the female sudents' strategies at the classroomand questions for the male and the female sudents' strategies out of the classroom.

Based on the anlysis of interview questions namely outsude and inside questions, it can be concluded that gender differences affect in choosing 
language learning strategies of the male and the female students at SMA Negeri 11 Makassar. As the result, mostly the males and the females had differences in choosing strategies for their learning English. The females that had characteristics like more emphatic and comprehension in thinking, their emotion influenced their decision, social thinking and liked cooperting with their peers refered to the social strategy while the males that had characteristics like making fun, more confident, logical, active in expressing their opinion refered to the compensation startegy.

Additionally, the different frequences of language learning strategies choice by the male and the female students at SMA Negeri 11 Makassar were supported exactly by the inside question in interview "How do you learn Englishat school?" and outside qustion "How do you learn English outsde school?". Their answers can be classified as language learning strategies chioce that are presented in table 11.

Table 11. The variation of the language learning strategies used between males and female students

\begin{tabular}{|c|c|c|c|}
\hline No. & Male Students & $\begin{array}{c}\text { Language Learning } \\
\text { Srategies }\end{array}$ & $\begin{array}{c}\text { Female } \\
\text { Students }\end{array}$ \\
\hline 1. & 6 of 15 males & Memory strategy & 3 of 15 females \\
2. & 10 of 15 males & Cognitive strategy & 9 of 15 females \\
3. & 11 of 15 males & Compensation strategy & 7 of 15 females \\
4. & 2 of 15 males & Metacognitive strategy & 6 of 15 females \\
5. & 5 of 15 males & Affective strategy & 5 of 15 females \\
6. & 7 of 15 males & Social strategy & 13 of 15 females \\
\hline
\end{tabular}

As indicated in table 14 that the most frequently used strategy by male students was compensation strategies, followed by cognitive, social, and memory strategy while affective strategy was the second least popular strategy and metacognitive strategy was the least frequently selected. For the female students, the most frequently used strategy was social strategy, followed by cognitive, compensation and metacognive strategy whereas affective strategy was the second least selected strategy and memory was the least frequently selected.

From its finding, it can show the male and female students at SMA Negeri 11 Makassar in selecting language learning strategies. Both male and female students had different rank strategies that is demonstrated in table 12 . 
Jamiah, Mahmud, Muhayyang: Do Male and Female Students Learn ... $\mid 121$

Table 12. The ranking of language learning strategies among males and females students

\begin{tabular}{|c|c|c|c|}
\hline No. & $\begin{array}{c}\text { Male students' } \\
\text { language learning } \\
\text { strategies }\end{array}$ & Rank & $\begin{array}{c}\text { Female students' language } \\
\text { learning strategies }\end{array}$ \\
\hline 1. & Compensation & 1 & Social \\
2. & Cognitive & 2 & Compensation \\
3. & Memory & 3 & Cognitive \\
4. & Social & 4 & Metacognitive \\
5. & Affective & 5 & Affective \\
6. & Metacognitive & 6 & Memory \\
\hline
\end{tabular}

The greatest difference was in the use of social strategies, which were ranked as the most popular strategies by females, but the fourth by males while the first rank of males was cognive strategy but the third by females. Memory strategy was the least ranked strategy by female but the third by the males while metacognitive strategy was the least ranked by males but the fourth by females. Affecive strategy was the fifth ranked strategy both males and female.

Based on the data above, that supported by many studies (Green and Oxford, 1995; Kato ,2005; Mahmud, 2010; Tam, 2013) have investigated the correlation between language learning strategy and gender differences. The result found that males and females used different strategy in learning English as a foreign language. Hence, it concluded that gender differences affect in choosing language learning strategies.

\section{Discussion}

This part provides the discussions of the observation and interview answered by the respondents regarding their language learning strategies as affected by gender differences. From the two points above, it can be concluded that both males and females had differences strategies in learning English. As indicated in table 4, 5, 6, 7, 8, and 9 in findings, the males and the females learnt differently. Even they used six language learning strategies but they had differences in applying them.

Based on the observation during three meetings, both male and female students had strategies to endure in learning English. For example, males were motivated by competition while females were not. Males were deductively reasoning. They tend to begin with concrete examples, especially in verbalization and writing, males also liked visual-auditory, for males, the most effective way to study language is to learn visually (seeing a written word or illustration) as well as orally (through listening and repetition), moreover, males also were highlighting and coordinating. 
They liked a simple thing, spesific point, and also good in coordination. Contradictly, females prefered collaborative group in learning. Other strategies were inductively reasoning, females begin with specific examples and build the general theory more often than males. Female also were organizing, they like making their schedule to manage when they need to learn and have fun. Besides that, they were auditory and personalizing. Even in learning, females preferedlistening, they gave their feelings as the priority. Females also were moody that is why their decision would be influenced by their emotions.

The data above were supported by some scholars (Gurian, 2001; Torrpra, 2008; Aslan, 2009; and Mahmud, 2010). The male and the female students had different strategies in learning English cited by Mahmud (2010). Proofed by the frequency of social strategy used in table 14 that the females used more than the males. It was similar with Aslan (2009:65) reported that females used more social strategy than their counterparts. It is supported also by Torrpra (2008:34) reports that females can process an abstract piece of language more efficiently while males need some sensory reinforcement to process the data. In deductive and inductive reasoning, Gurian (2001) states the males tend to do deductive reasoning more quickly than girls. Females, on the other hand, tend to favor inductive thinking.

Then, results of this research also carried out by interview as indicated in table 13 that gender has a significant effect on the frequency of strategy use. Based on the interview, one of the male answered, "Eeee... kalau saya lebih ke audio. Mendengarkan. Lebih senang mendengarkan saja, Kak" (Mmm.. I mostly like audio. Listening. I pefer listening only, Sister").While one of female answered, "Biasanya kalau di kelas, tanya teman atau google, Kak" ("I usually ask my friends or browse via internet, Sister"). From that data above, it can be concluded that males and females had different preference in learning English. Regarding their strategies, gender differences affect in choosing language learning stratgies.

Supported by the some scholars (Lakoff, 1976; Tannen, 1990; Tymson, 1998; and Mahmud, 2010) that investigated about gender in communication. One characteristic of women's language stated by Lakoff (1976) is the great tendency of women in using tag questions (she's very nice, isn't she?). The use of tag question showed the doubt and shyness in giving opinion. It revealed incline passifity in communication.

Other research on language and gender also indicated the different tendencies between the males and the females in using language for communication. Tannen (1990) believed that women related intimacy through communication in their relationship. They communicate their feelings, when she opens up to a person she is trying to connect with whom she is talking to while men do not find the same value in communicating their feelings as often as women for that is placing the man a step closer to being a woman. 
The discourse about males and females differences in communication also reported by Tymson (1998:8). The males in communication style tend to show that they focused on information while females focused on relationship. Other style also showed that males were report style of speaking however, females were rapport style of speaking. The data showed that females liked the complete and clear instructions, different with males that liked spesific and direct in giving information.

Another difference is that the females were more collaborative than the males. In learning English, they cooperated with others. Same evidence also came from Eckert and McConnel-Ginet (1994:453) in Mahmud (2010) reported that women's language is said to reflect 'women's conservatism, prestige consciousness, desire for upward mobility, insecurity, deference, nurture, emotional expressivity, connectedness, sensitivity to others, and solidarity'.

\section{Conclusionand Suggestions}

Based on the findings and discussion of the research, it can be concluded thatmale and female second grade students of SMA Negeri 11 Makassar learn differently. Both male and female used six language learning strategies namely memory strategy, cognitive strategy, compensation strategy, metacognitive strategy, affective strategy and social strategy, where the most strategies that selected by males were compensation strategy while social strategy for females. It is revealed that differences on the ways of males and females' strategies as discussed on the literature of gender, as promoted by Mahmud (2010) and Aslan (2009) that female and male students have different strategies in learning English. Females used more social strategy than their counterparts. (2) Gender differences affect second grade students in choosing language learning strategies of SMA Negeri 11 Makassar. The females that like discussing when learning English, good in social thinking and interaction refer to the social strategy while the males that were active in expressing their idea, logical and better in coordination refer to compensation strategy. Their characteristics strongly influenced their language learning strategy choice in learning English. As noted by Tymson (1998:8) and Tannen (1990) about the different tendencies between men and women in using language for communication, they believed male in communication style tend to show that they focused on information while females focused on relationship.

Based on result of data analysis and conclusion above the researcher presents the following suggestion. These findings provided useful information for teachers to provide language learning strategies. The teachers should be aware that students with different gender, behave differently in learning 
English. In order to fill the needs of students, these factors should be consideredin designing learning and teaching process on language learning strategies.

\section{References}

Aslan, O. (2009). The Role of Gender and Language Learning Strategies in Learning English. Unpublished Thesis. The Degree of Master of Arts in The Department of English Language Teaching. Middle East Technical University.

Božinovi ć, N. (2011). Gender Differences in the Use of Learning Strategies in Adult Foreign Language Learners. American College of Management and Technology.

Cabaysa, C. C. (2010). Language Learning Strategies of Students at Different Levels of Speaking Proficiency. Education Quarterly, December, Vol. 68 (1), 16-35 U.P. College of Education.

Eckert, \& McConnell-Ginet, S. (2003).Language and Gender. New York: Cambridge University Press.

Gurian, M. (2001). Boys and Girls Learn Differently!. San Fransisco, CA: JosseyBass. Kato, S. 2005. How Language Learning Strategies Affect English Proficiency in Japaese University Students. Journal of the Faculty of Human Studies Bunkyo Gakuin University 7.1: 239-262.

Lakoff, R. (1975). Language and Woman's Place.Language in Society.Vol. 2, No. 1 (Apr., 1973), pp. 45-80.Cambridge University Press Stable URL: http://www.jstor.org/stable/4166707

Lee, C. K. (2010). An Overview of Language Learning Strategies. Arecls, 2010, Vol.7, 132-152.

Mahmud, M. (2008). Bahasa dan Gender dalam Kinerja Organisasi (Language and Gneder in Organizations). Jurnal Administrasi Publik Volume IV No 3 September 2008, Published by Pusat Kajian dan Pendidikan dan Pelati- han Aparatur II LAN, Makassar.

Mahmud, M. (2009a). Bahasa Perempuan: Refleksi Gender dalam Kinerja dan Kepemimpinan Organisasi (Women's Language: Its Reflection on Organizational Leadership). Proceeding of the National Seminar on Gender Perspective Leadership at the Center of Women Studies, Gadjah Mada University, 18 Juni 2009. 
Jamiah, Mahmud, Muhayyang: Do Male and Female Students Learn ... 125

Mahmud, M. (2009b). Bahasa dan Gender dalam Masyarakat Bugis. Makassar, Indonesia: Pustaka Refleksi.

Mahmud, M. (2010). Language and Gender in English Language Teaching. TEFLIN Journal,Volume 21, Number 2, August 2010.

Oxford.Dictionary. (1995). Oxford University Press.

Oxford, R. (1990). Language Learning Strategies: What Every Teacher should Know. New York, NY: Newbury House. Oxford, Rebecca. 1992. Language learning strategies in a nutshell: Update and ESL suggestions. TESOL Journal 2.2: $18-22$.

Oxford, R. (1993). Gender Differences in Styles and Strategies for Language Learning: What Do They Mean? Should We Pay Attention? In Alatis, J. (Ed.). Strategic Interaction and Language Acquisition: Theory, Practice, and Research (pp. 541-557). Washington, DC: Georgetown University Press.

Oxford, R. (2003). Language Learning Styles and Strategies: An Overview. Learning Styles \& Strategies. GALA, 2003 on web.ntpu.edu.tw/ language/workshop/read2.pdf

Tam, K. (2013). A Study on Language Learning Strategies (LLSs) of University Students in Hong Kong. Unpublished Thesis. The University of Hong Kong.

Tannen, D. (1990). You Just Don't Understand: Women and Men in Conversation. New York: Harper Collins. 